\title{
Potensi Pengembangan Budidaya Ulat Sutera di Areal KPHP Model Awota
}

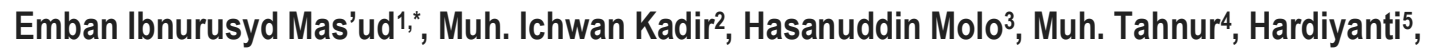 \\ Selamet Riyadi ${ }^{6}$
}

${ }^{1}$ Fakultas Kehutanan, Universitas Hasanuddin

2Fakultas Pertanian, Universitas Islam Makassar

${ }^{3}$ Fakultas Pertanian, Universitas Muhammadiyah Makassar

4Kesatuan Pengelolaan Hutan Produksi (KPHP) Model Awota

${ }^{5}$ Balai Pengelolaan Hutan Produksi Wilayah XIII Makassar

*E-mail: emban.masud@gmail.com

\begin{abstract}
The dialectics between local government interest versus the central government in forestry sector are the main topics of forestry today. Natural silk management is the interest of local government that has been assimilated into Forest Management Unit (KPH)in the form of KPHP Awota Model Awota. Until now, there is no scientific study on the potential of silkworm cultivation development in this areal. Therefore this study aims to analyze the potential of silkworm cultivation development. This potential in question is the institutional system, biophysical potential, environmental potential, market potential and financial value. The results showed that the development of silkworm cultivation in KPHP Awota Model area has the advantage of biophysical potential, environmental potential, marketing potential and financial value. However, this activity has an obstacles in the institutional issues primarily in the management of silkworm cultivation from upstream to downstream sectors.
\end{abstract}

Keywords: awota; cultivation; forest management unit; silk worm DOI: $10.24259 / \mathrm{jhm} . v 9 i 1.2015$

\section{PENDAHULUAN}

Kain sutera di Indonesia merupakan salah satu ciri khas produk budaya lokal etnis Bugis. Hal ini dapat terlihat melalui ikon Kabupaten Wajo, yang merupakan wilayah masyarakat etnis bugis, yaitu "Kota Sutera". Produk sutera merupakan hasil pengolahan benang sutera. Untuk mendapatkan benang sutera maka membutuhkan sebuah proses budidaya ulat sutera. Sadapotto (2012) berpendapat bahwa budidaya ulat sutera pernah menjadi salah satu mata pencaharian utama masyarakat Kabupaten Wajo dan hingga saat ini masih ada walaupun telah mulai berkurang, beberapa wilayah masih tetap mempertahankan sistem mata pencaharian tersebut.

Dalam rangka mempertahankan eksistensi budidaya sutera alam, Pemerintah Kabupaten Wajo menginisiasi Kesatuan Pengelolaan Hutan yang berbasis sutera alam. Inisiasi ini merupakan dukungan pemerintah berupa pengelolaan lahan hutan negara untuk mendukung tujuan pelestarian pengelolaan sutera alam di Kabupaten Wajo. Tujuan ini mendapatkan legalitas berdasarkan Keputusan Menteri Kehutanan No. SK.88/Menhut-II/2011 berupa pembentukan Kesatuan Pengelolaan Hutan Produksi (KPHP) Model Awota.

Realitas di atas menunjukkan bahwa Pemerintah Daerah memiliki ekspektasi besar terhadap KPHP Model Awota. Hal ini menimbulkan pertanyaan: Bagaimana potensi pengembangan budidaya ulat sutera (Bombyx mori) di areal KPHP Model Awota? Berdasarkan permasalahan yang dipaparkan maka peneliti menganggap penting penelitian terkait potensi pengembangan budidaya ulat sutera di Areal KPHP Model Awota. 
Penelitian ini bertujuan untuk menganalisis potensi pengembangan budidaya ulat sutera di areal KPHP Awota. Hasil penelitian ini bermanfaat sebagai bahan dasar penyusunan strategi dan model pengelolaan sutera alam di areal KPHP Awota.

\section{METODE PENELITIAN}

Penelitian ini dilaksanakan pada bulan Desember 2015 hingga Juli 2016. Tempat penelitian dilaksanakan di areal KPHP Model Awota, Industri pengolahan benang sutera, Kantor Dinas Kehutanan Kabupaten Wajo, Kantor Desa se-Kabupaten Wajo dan Kantor KPHP Model Awota. Penelitian ini dilaksanakan sebanyak empat tahap secara berurutan dapat dilihat di bawah ini:

1. Tahap desk study dilaksanakan pada tahap awal dengan melakukan penelitian terhadap produk-produk hukum terkait pengelolaan sutera alam di Kabupaten Wajo dan review dokumen penelitian mengenai sutera alam dan KPHP Model Awota.

2. Tahap observasi lapangan. Tahap ini menggunakan metode Participatory Action Research (PAR) yaitu Transect Walk dan Semi Structured Interview. Objek observasi merupakan stakeholder terkait pengelolaan sutera alam di Kabupaten Wajo yaitu pihak manajemen KPHP Awota, pihak Dinas Kehutanan Kabupaten Wajo, Dinas Perindustrian Kabupaten Wajo, Pihak Kementerian Kehutanan yang mengurusi masyarakat yang berada di areal KPHP Awota, kepala desa wilayah yang berada di areal KPHP Awota, tokoh masyarakat setempat, masyarakat yang terkena dampak (termasuk ibu rumah tangga) dengan adanya KPHP Awota, pihak industri sutera serta konsumen kain sutra.

3. Tahap analisis dilaksanakan untuk mendiseminasi data-data yang telah diperoleh melalui Tahap 1 dan Tahap 2. Proses diseminasi dihasilkan melalui melalui pendekatan kualitatif dan kuantitatif.

Analisis data yang digunakan dalam penelitian ini adalah analisis kualitatif dengan model Miles dan Huberman (1984). Menurut Miles dan Huberman aktivitas dalam analisis data kualitatif dilakukan secara interaktif dan berlangsung secara terus menerus sampai tuntas. Aktivitas dalam analisis data, yaitu: (1) data reduction, (2) data display, dan (3) conclusion. Analisis ini dilakukan untuk mendeskripsikan potensi kelembagaan, potensi biofisik, potensi lingkungan dan potensi pemasaran. Analisis data kuantitatif dilaksanakan untuk mengukur nilai finansial budidaya ulat sutera. Analisis ini menggunakan rumus Net Return at the End of Rotation. Adapun rumus tersebut:

NRER $=\sum_{j=0}^{t}(B t-C t)(1+i)^{t-j}$

Keterangan:

$\begin{array}{ll}\text { NRER } & \text { : Pendapatan padaakhir rotasi } \\ \text { Bt } & \text { : Pendapatan tahun ke-t } \\ \text { Ct } & : \text { Biaya tahun ke-t } \\ \text { j } & : \text { Tahun berjalan } \\ \mathrm{t} & \text { : Umur rotasi } \\ \text { I } & \text { : Nilai suku bunga }\end{array}$




\section{HASIL DAN PEMBAHASAN}

\subsection{Potensi Kelembagaan}

Pelaksanaan pengelolaan hutan yang ideal membutuhkan pola hubungan antar anggota yang dinamis dan positif. Pola hubungan ini menurut Djogo, dkk. (2013) adalah kelembagaan. Secara umum kelembagaan budidaya persuteraan alam dalam ruang lingkup wilayah KPHP Model Awota memiliki jaringan stakeholder utama yaitu pihak manajemen KPHP Awota dan masyarakat di dalam serta di sekitar areal kawasan hutan KPHP Model Awota.

1. Peran institusi

Inisiasi pengembangan budidaya sutera alam di areal KPHP Model Awota merupakan kebijakan yang bersifat top-down. Kebijakan ini lahir karena keinginan pemerintah untuk mempertahankan eksistensi budaya "sutera" di Kabupaten Wajo.

Implikasi kebijakan di atas adalah tingginya eskalasi konflik yang terjadi antara pihak manajemen KPHP dengan calon pihak pengelola. Konflik ini didasari atasKemunculan KPHP pada tahap awal pembentukannya telah bersinggungan dengan lahan yang diklaim masyarakat sebagai lahan miliknya. Klaim lahan masyarakat didasari oleh bukti pajak tanah atau nota pembelian tanah.

Mengantisipasi paradoks di atas, pihak manajemen KPHP Awota menggunakan model komunikasi partisipatif dalam memecahkan konflik. Hal ini terlihat melalui terbangunnya kesepakatan bersama antara masyarakat (yang mengklaim lahan negara) dengan pihak manajemen dalam membentuk model pengelolaan melalui skim kemitraan.

Peran yang berbeda dimiliki oleh masyarakat dan di dalam sekitar hutan. Keinginan untuk beraktifitas secara legal di dalam kawasan hutan negara menjadi faktor pendorong masyarakat menyepakati kolaboarasi dengan pihak manajemen KPHP Model Awota. Namun, hal ini masih belum ideal karena masyarakat saat ini masih terbiasa dengan aktifitas budidaya tanaman pertanian secara monokultur. Pengalaman masyarakat membudidayakan ulat sutera juga sudah tidak ada.

Pembahasan mengenai peran institusi menunjukkan bahwa bentuk pengelolaan sutera alam dalam upaya mengembangkan budidaya ulat sutera di areal KPHP Model Awota menggunakan pendekatan kelembagaan konvensional disipliner. Djogo, dkk. (2013) memperingatkan bahwa pendekatan ini berpotensi mengaburkan nilai manfaat dari analisis biaya-keuntungan (cost-benefit).

2. Modal sosial

Modal sosial penelitian ini menggunakan pendekatan Fukuyama (2000; 2001) dan Hasbullah (2006) yaitu sekumpulan nilai-nilai informal yang memungkinkan terjalinnya kerjasama kelompok. Nilai-nilai informal yang dimaksud adalah trust, reciprocal, dan social network.

Modal sosial pertama yang dianalisis adalah Trust atau rasa percaya. Hasil penelitian menunjukkan bahwa masyarakat memiliki rasa kepercayaan yang rendah antar individu di dalam kelompok masyarakat.Hal ini didasari oleh persepsi masyarakat "masyarakat vs pemerintah" yang berimplikasi pada pandangan "masyarakat vs masyarakat pro pemerintah".

Modal sosial berikutnya adalah reciprocalyang berarti kemampuan saling tukar kebaikan antar individu dalam suatu kelompok. Terkait masyarakat yang berpotensi terlibat pada kegiatan budidaya sutera alam di areal KPHP Awotamenunjukkan bahwa kondisi seluruh masyarakat melaksanakan adat istiadat Bugis Wajo melalui prinsip nilai 3S yaitu Sipakattau (saling menghargaisesama manusia), Sipakalebbi (saling menghormati), dan Sipakainge (saling mengingatkan). Melalui prinsip nilai maka sistem yang terbangun di masyarakat adalah sistem yang mengedepankan nilai-nilai kekeluargaan yang sangat menghargai orang tua (untuk konteks dinamika masyarakat orang tua tercermin melalui tokoh-tokoh masyarakat). Prinsip ini pula yang membentuk perilaku altruisme masyarakat. 
Modal sosial terakhir adalah social network. Perilaku altruisme masyarakat membantu mereka membentuk jejaring intra masyarakat yang kuat. Namun, masyarakat memiliki kekurangan dalam menjalin jejaring ke luar komunitasnya. Jejaring yang terbentuk selama lima tahun terakhir terbentuk melalui intervensi pihak pemerintah dalam memberikan insentif baik di bidang pertanian, kehutanan, perkebunan dan peternakan. Arah jejaring sosial dalam pengembangan unit usaha saat ini memiliki tingkat ketergantungan yang tinggi terhadap pemerintah dan pasar.

Ketiga elemen di atas menunjukkan bahwa modal sosial yang terbentuk di masyarakat cenderung mengarah kepada bonding social capital (jaringan sosial yang terbentuk antara pihak-pihak yang homogen). Hal ini menjadi tantangan karena dengan adanya KPHP Model Awota maka bentuk modal sosial yang awalnya bonding social capital bertransformasi menjadi bridging social capital (jaringan sosial antara pihak-pihak yang heterogen).

Peran institusi dan modal sosial menunjukkan potensi permasalahan yang akan dihadapi oleh pihak manajemen KPHP Model Awota melaksanakan budidaya ulat sutera. Dalam konteks paradigma perubahan (Suradisastra, 2008), kondisi di atas menunjukkan gejala paradigma evolutif. Paradigma ini cenderung berlangsung lama dalam mencapai tujuan. Hal ini merupakan paradoks pengelolaan hutan di Indonesia yang membutuhkan intervensi yang cepat dalam mengantisipasi laju kerusakan hutan yang terus terjadi.

\subsection{Potensi Biofisik dan Lingkungan}

Budidaya ulat sutera membutuhkan 2 aktifitas utama yaitu pengelolaan pakan ulat sutera berupa murbei (Morus) dan pengelolaan ulat sutera. Kedua aktifitas ini menjadi dasar eksplorasi potensi biofisik dan lingkungan.

Secara biofisik, areal KPHP Model Awota di dominasi oleh lahan pertanian kering bercampur semak, tambak dan semak/belukar (KPHP Model Awota, 2015). Hasil analisis di lapangan menunjukkan produksi pertanian utama masyarakat di dalam kawasan hutan adalah padi (Oryza sativa) dan jagung (Zea mays). Hal yang cenderung sama dilaksanakan oleh masyarakat yang berada di sekitar areal KPHP Model Awota. Interaksi zat kimia terhadap murbei dapat

Kondisi areal KPHP Model Awota berada dalam batas toleransi ketinggian pengelolaan pakan murbei yaitu antara $200 \mathrm{mdpl}$ sampai dengan 1200 mdpl. Rata-rata kelerengan lahan adalah landai dan hal ini merupakan kelerengan yang sangat tepat untuk mengelola tanaman murbei. Selain batas ketinggian dan kelerengan,tipe iklim di areal KPHP Model Awota adalah C1, D1, D2, E2 dan E3 (BPS, 2015) dan hal ini masih dalam batas kewajaran iklim budidaya murbei.

Potensi lingkungan turut mendukung budidaya ulat sutera. Penelitian ini mengelaborasi budidaya ulat sutera melalui tingkat ketertarikan masyarakat melakukan pengelolaan ulat sutera dan tingkat ketertarikan masyarakat melakukan pengelolaan murbei untuk kebutuhan pakan ulat sutera. 


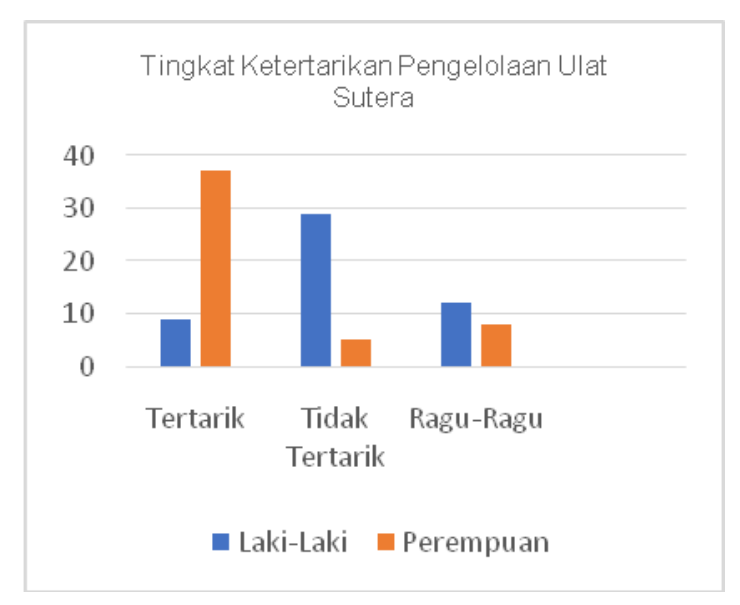

\section{Gambar 1. Tingkat Ketertarikan Pengelolaan Ulat Sutera}

Gambar 1. menunjukkan bahwa masyarakat lebih dominan tertarik untuk mengelola ulat sutera. Secara spesifik, masyarakat berjenis kelamin perempuan memberikan kontribusi ketertarikan yang sangat tinggi dibandingkan dengan jenis kelamin laki-laki. Fenomena menarik menunjukkan bahwa masyarakat berjenis kelamin laki-laki mendominasi tingkat ketidaktertarikan pengelolaan ulat sutera.

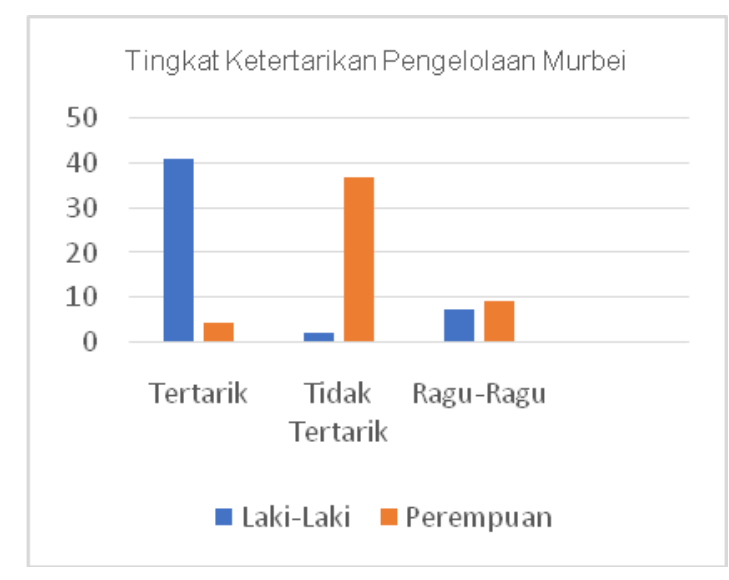

\section{Gambar 2. Tingkat Ketertarikan Pengelolaan Murbei}

Gambar 2 memberikan informasi bahwa untuk pengelolaan murbei, masyarakat juga tertarik untuk melaksanakannya. Namun secara spesifik, jenis kelamin laki-laki lebih dominan tertarik (45\%) sedangkan perempuan tidak tertarik $(39 \%)$.

Merujuk pada kedua data di atas, maka secara umum dapat disimpulkan bahwa masyarakat cenderung tertarik melakukan budidaya ulat sutera namun pada prosesnya masyarakat yang berjenis kelamin laki-laki lebih menyukai untuk mengelola lahan menghasilkan murbei sedangkan masyarakat yang berjenis kelamin perempuan lebih menyukai pengelolaan ulat suteranya. Hal ini dapat menjadi kombinasi di dalam 
skala rumah tangga yang memberikan peranan terhadap laki-laki dan perempuan dalam upaya meningkatkan kesejahteraan rumah tangga.

\subsection{Potensi Pemasaran dan Nilai Finansial}

Potensi pasar budidaya ulat sutera tergolong tinggi di Kabupaten Wajo. Data Rencana Pengelolaan Hutan Jangka Panjang KPHP Awota (2015) menunjukkan bahwa alat tenun mesin di Kabupaten Wajo sebanyak 60 unit, alat tenun bukan mesin sebanyak 1.246 unit, dan gedongan sebanyak 2.078 unit. Apabila dikalkulasikan maka kebutuhan benang untuk seluruh alat tenun tersebut adalah antara 200-300 ton benang/tahun.

Potensi pasar di atas didukung oleh nilai finansial budidaya ulat sutera yang layak. Hasil analisis Net Return at the End of Rotation budidaya ulat sutera sebesar Rp.20.736.545. Nilai analisis ini merupakan penilaian kegiatan budidaya ulat sutera mulai dari persiapan pakan hingga menghasilkan benang sutera. Untuk kegiatan persediaan pakan maka lahan dikelola berdasarkan keinginan masyarakat yang menerapkan pola agroforestri. Adapun pola yang dipilih adalah kombinasi antara tanaman jabon (Anthocepalus macrophyllus) atau jati putih (Gmelina arborea) dengantanaman murbei.

\section{KESIMPULAN}

Pengembangan budidaya ulat sutera di areal KPHP Model Awota memiliki keunggulan potensi biofisik, potensi lingkungan, pemasaran dan nilai finansial. Namun, kegiatan ini memliki hambatan berupa persoalan kelembagaan utamanya sistem yang mengatur pengelolaan budidaya ulat sutera dari sektor hulu ke sektor hilir.

\section{DAFTAR PUSTAKA}

Djogo, Tony., Suharjito, Didik., dan Sirait, Martua. 2013. Kelembagaan dan Kebijakan dalam Pengembangan Agroforestri. Bogor: World Agroforestry Centre (ICRAF) Southeast Asia.

Fukuyama, Francis. 2000. The Great Depression: Human Nature and the Reconstitution of Social Order. London: Profile Book.

Fukuyama, Francis. 2001. Social Capital, Civil Society and Development. Thir World Quarterly, Vol 22, No 1, pp 7-20.

Hasbullah, Jousairi. 2006. Social Capital (Menuju Keunggulan Budaya Manusia Indonesia). Jakarta: MRUnited Press.

Kementerian Kehutanan. 2013. Surat Keputusan Menteri Kehutanan RI Nomor: SK.979/Menhut-II/2013 tanggal 2727 Desember 2013 tentang Penetapan Areal KPHP Model Awota. Jakarta.

Kesatuan Pengelolaan Hutan Produksi Model Awota. 2015. Rencana Pengelolaan Hutan Jangka Panjang KPHP Model Awota. Sengkang.

Pemerintah Kabupaten Wajo. 2010. Peraturan Bupati Wajo Nomor 21 Tahun 2010 tentang Pembentukan Unit Pelaksana Teknis Dinas (UPTD) Kesatuan Pengelolaan Hutan Produksi (KPHP) Awota. Sengkang. 